\title{
Zoledronic acid induces antiproliferative and apoptotic effects in human pancreatic cancer cells in vitro
}

\author{
P Tassone ${ }^{1,2,4}$, P Tagliaferri $^{1,4}$, C Viscomi $^{1}$, C Palmieri', M Caraglia $^{3}$, A D'Alessandro ${ }^{3}$, E Galea', A Goel $^{2}$, \\ A Abbruzzese ${ }^{3}$, CR Boland ${ }^{2}$ and S Venuta*,I \\ 'Oncology Unit, Department of Experimental and Clinical Medicine, Via T. Campanella, II 5 'Magna Græcia' University, 88 I00 Catanzaro, Italy; \\ ${ }^{2}$ Department of Medicine and Comprehensive Cancer Center, University of California, San Diego, La Jolla, CA, USA; ${ }^{3}$ Department of Biochemistry \\ and Biophysics, II University of Naples, Italy
}

Bisphosphonates (BPs) are an emerging class of drugs mostly used in the palliative care of cancer patients. We investigated the in vitro activity of the most potent antiresorptive BP, zoledronic acid (ZOL), on the growth and survival of three human pancreatic cancer (PC) cell lines (BXPC-3, CFPAC-I and PANC-I). Pancreatic cancer frequently has a dysregulated $\mathrm{p} 2 \mathrm{I}^{\text {ras }}$ pathway and therefore appears to be a suitable target for BPs that interfere with the prenylation of small GTP-binding proteins such as $\mathrm{p} 2 \mathrm{I}^{\text {ras }}$. We found that $\mathrm{ZOL}$ induces growth inhibition $\left(\mathrm{IC}_{50}: \mathrm{I} \mathrm{O}_{-50} \mathrm{\mu M}\right)$ and apoptotic death of PC cells. The proapoptotic effect was correlated to cleavage/ activation of caspase-9 and poly(ADP)-ribose polymerase, but not of caspase-3. Moreover, we studied the $\mathrm{p} 2 \mathrm{I}^{\text {ras }}$ signalling in cells exposed to ZOL and detected a reduction of $\mathrm{p} 2 \mathrm{I}^{\text {ras }}$ and Raf-I content and functional downregulation of the terminal enzyme ERK MAPkinase and of the pKB/Akt survival pathway. Finally, we observed that ZOL induces significant cytoskeletal rearrangements. In conclusion, we demonstrated that ZOL induces growth inhibition and apoptosis on PC cells and interferes with growth and survival pathways downstream to $\mathrm{p} 2 \mathrm{I}^{\mathrm{ras}}$. These findings might be relevant for expanding application of BPs in cancer treatment.

British Journal of Cancer (2003) 88, 197I-1978. doi:I0.1038/sj.bjc.6600986 www.bjcancer.com

(c) 2003 Cancer Research UK

Keywords: pancreatic cancer; zoledronic acid; zoledronate; zometa; bisphosphonates; caspase-9; p2 ${ }^{\text {ras }}$; apoptosis

Cancer of the exocrine pancreas is the fourth leading cause of cancer-related deaths in both men and women (Fernandez et al, 1994). Even if advances in surgical techniques, radiation and chemotherapy have provided significant improvements in the overall survival and on the quality of life, fewer than $5 \%$ of pancreatic cancer (PC) patients survive 5 years after diagnosis (Parker et al, 1996). Therefore, it is not surprising that PC is a serious health problem. Thus, there is a great demand for new and more effective therapeutic strategies for the treatment of this disease. Recent studies on pancreatic tumour tissues and cell lines have shown that multiple subsets of genes undergo activation or inactivation during development and progression of disease (Hilgers and Kern, 1999). Specific point mutations at codon 12 of the K-ras oncogene are detected in $75-90 \%$ of PC specimens and constitute the most common genetic changes in PC (Almoguera et al, 1988). The mutated K-ras protein is not able to convert GTP to GDP, resulting in constitutively active GTPbound species and constitutive activation of cell proliferative signals. It is therefore conceivable that the pancreatic carcinogenetic process and/or the maintenance of the transformed phenotype strongly rely on the dysregulated activity of the p $21^{\text {ras }}$-mediated signalling. The inhibition of $\mathrm{p} 21^{\text {ras }}$ signalling has therefore been postulated as a possible target for anticancer therapy and might be specifically suitable for the treatment of PC.

\footnotetext{
*Correspondence: Prof S Venuta; Email: oncologia@unicz.it

${ }^{4}$ Both authors contributed equally to the work.

Received 30 October 2002; revised I 8 March 2003; accepted 19 March 2003
}

Bisphosphonates (BPs), the most effective and widely used class of drugs in the treatment of metabolic bone disorders, including tumour-associated bone disease, are capable of inhibiting p $21^{\text {ras }}$ signalling (Luckman et al, 1998; Green, 2001). Therefore, the extensive evaluation of these compounds, and particularly the study of the recently available and more potent nitrogen-containing BPs, may suggest expanding applications of these drugs and warrant further investigation. It is well known that BPs are compounds that strongly bind to hydroxyapatite crystals and accumulate in mineralised bone (Jung et al, 1973). Bisphosphonates, which are specifically internalised into osteoclasts (Sato et al, 1991), lead to inhibition of cell function because of changes in the cytoskeleton and loss of the ruffled border (Carano et al, 1990), as well as apoptosis (Hughes et al, 1995). Thirdgeneration, nitrogen-containing BPs, such as zoledronic acid (ZOL) (Green et al, 1994), inhibit farnesyldiphosphate (FPP) synthase, an enzyme involved in the mevalonate pathway (Luckman et al, 1998; Benford et al, 1999), preventing post-translational events of prenylation of small GTP-binding proteins such as $\mathrm{p} 21^{\text {ras }}$, Rab, Rho, Rac and cdc42 (Luckman et al, 1998), which are required for a variety of biological functions including signal transduction and cell adhesion.

In addition to the potent antiresorptive effects of nitrogencontaining BPs, recent reports have also shown that these compounds induce antiproliferative and apoptotic effects in multiple myeloma cells in vitro (Shipman et al, 1997; Aparicio et al, 1998), may synergise with chemotherapeutic or biological agents (Tassone et al, 2000, 2002), and may offer clinical benefits (Dhodapkar et al, 1998; Berenson et al, 1998). A direct effect induced by BPs has also been demonstrated on tumour cells of 
nonhaematopoietic origin. Bisphosphonates induce inhibition of adhesion of breast and prostate cancer cells to bone matrix (Van Der et al, 1996; Boissier et al, 1997). In a mouse model of breast cancer, BPs inhibited the progression and the development of bone metastasis (Sasaki et al, 1995). Other studies have also suggested that BPs may interfere with the growth and survival of metastatic cancer cells in bone (Pelger et al, 1998). More recently, a variety of studies have focused on the direct effect of BPs on growth and survival of cancer cells from solid tumours. ZOL induces a significant reduction of cell viability, increases apoptotic cell death and downregulation of bcl- 2 protein, $\mathrm{p} 21^{\text {ras }}$ delocalisation from the cell membrane and proteolytic cleavage of PARP, indicating direct antitumour effects on human breast cancer cells (Senaratne et al, 2000; Senaratne et al, 2002). In prostate cancer cells, ZOL has shown a remarkable inhibitory effect on cell proliferation by induction of cell death and/or cytostasis in vitro (Lee et al, 2001).

In this scenario, since there have been no studies addressing the possibility of a direct effect of BPs on growth and survival of human PC cells, we studied the activity of the most potent BP, ZOL, on a panel of different human PC cell lines (BxPC-3, CFPAC1 and PANC-1). We have additionally studied whether the nitrogen-containing ZOL might induce effects on the $\mathrm{p} 21^{\mathrm{ras}} / \mathrm{raf} 1 /$ MEK1/ERK and on the pkB/Akt pathways, and if apoptosis should be related to caspase-9/-3 and PARP cleavage/activation in these cancer cells.

\section{MATERIALS AND METHODS}

\section{Cell cultures and reagents}

The PC cell lines BxPC-3, CFPAC-1 and PANC-1 were purchased from the American Type Culture Collection (Rockville, MD, USA). BxPC-3 and CFPAC-1 are adherent human pancreatic adenocarcinoma cell lines that were grown in RPMI 1640 and Iscove's modified Dulbecco's media, respectively. PANC-1 is a human epithelioid pancreas carcinoma cell line that was grown in Dulbecco's modified Eagle's medium (DMEM). All media were supplemented with $10 \%$ heat-inactivated fetal bovine serum, $2 \mathrm{~mm}$ L-glutamine, $100 \mu \mathrm{g} \mathrm{ml}^{-1}$ streptomycin and $100 \mathrm{U} \mathrm{ml}^{-1}$ penicillin. All PC cell lines were cultured at a constant temperature of $37^{\circ} \mathrm{C}$ in a humidified atmosphere of $5 \%$ carbon dioxide $\left(\mathrm{CO}_{2}\right)$. The bisphosphonic acid monohydrate ZOL, 1-hydroxy-2-[(1H-imidazol1 -yl) ethylidene], a third-generation $\mathrm{BP}$, was kindly provided as the hydrated disodium salt by Novartis Pharma AG (Basel, Switzerland). The neutralised sodium salt of ZOL was dissolved in sterile $\mathrm{ddH}_{2} \mathrm{O}$ and used at a final concentration in a range of $1-100 \mu \mathrm{M}$. Stock solutions of $\mathrm{ZOL}$ were aliquoted and kept at $-20^{\circ} \mathrm{C}$ for longterm storage. Anti-caspase-9/-3 and anti-PARP MAbs were purchased from New England Biolabs (Beverly, CA, USA). Protein sepharose was purchased from Sigma (St Louis, MO, USA). Rabbit antisera raised against raf-1 C-12, $\beta$ actin, ERK-1 K-23 and ERK-2 MAb C-14 were purchased from Santa Cruz Biotechnology (Santa Cruz, CA, USA). Anti-pan-ras MAb clone 10 was purchased from Calbiochem (San Diego, CA, USA). Anti-Akt MAbs, GSK3 $\beta$ fusion protein and anti-pGSK $3 \beta$ MAbs were all from Cell Signaling Tech. (Beverly, MA, USA).

\section{Cell proliferation assay}

Analysis of cell proliferation was performed on PC cells in the presence of increasing concentrations of ZOL by the MTT assay. Briefly, PC cells $\left(3 \times 10^{4}\right.$ well $\left.^{-1}\right)$ were seeded in 96 -well plates in serum-containing media and allowed to attach for $24 \mathrm{~h}$. The medium was then removed and replaced with new medium containing ZOL at different concentrations. Cells were incubated under these conditions for a time course spanning $72 \mathrm{~h}$. Then cells were incubated with $10 \mu \mathrm{l} \mathrm{well}^{-1}$ of thiazolyl blue (MTT, $5 \mathrm{mg} \mathrm{ml}^{-1}$, Sigma) for $1 \mathrm{~h}$ at $37^{\circ} \mathrm{C}$. After incubation, $100 \mu \mathrm{l}$ of $0.04 \mathrm{~N} \mathrm{HCl}$ in isopropanol was added into each well and the absorbance was measured at a wavelength of $620 \mathrm{~nm}$ in a microplate reader. A value of $100 \%$ was assigned to untreated control cultures, and the $\mathrm{IC}_{50}$ was defined as the concentration of drug that reduced the number of viable cells to $50 \%$ of the control cultures after $72 \mathrm{~h}$ of exposure.

\section{Flow cytometric analysis of apoptosis}

Apoptotic cell death was analysed by Annexin-V-FITC staining and by propidium iodide (PI) detection systems. Annexin-V-FITC binds to phosphatidylserine residues, which are translocated from the inner to the outer leaflet of the plasma membrane during the early stages of apoptosis. Labelling of apoptotic cells was performed using an Annexin-V kit (MedSystems Diagnostics, Vienna, Austria). Briefly, cells were incubated with Annexin-VFITC in a binding buffer (provided by the manufacturer) for $10 \mathrm{~min}$ at room temperature, washed and resuspended in the same buffer as described by the manufacturer. Analysis of apoptotic cells was performed by flow cytometry (FACScan, Becton Dickinson). Propidium iodide analysis of apoptosis was performed using a commercial kit (MedSystems Diagnostics, Vienna, Austria). The cells were washed in PBS, resuspended in $190 \mu$ l of prediluted binding buffer $(1: 4)$ and incubated for $10 \mathrm{~min}$ with $10 \mu \mathrm{l}$ of the $20 \mu \mathrm{g} \mathrm{ml}^{-1}$ propidium iodide stock solution, and then the apoptotic cells were analysed by FACScan flow cytometer. For each sample, $2 \times 10^{4}$ events were acquired. Analysis was carried out by triplicate determination on at least three separate experiments. Induction of apoptotic cell death was further performed in the presence or absence of specific caspase inhibitors: VAD-fmk(-fluoromethylketone) which is a caspase-9 inhibitor, VEID-fmk which is specific for caspase-6 and DEVDfmk which is a caspase- 3 inhibitor.

\section{Immunoblotting for $\mathrm{p} 21^{\text {ras }}$, raf-1, ERK, pERK, caspase-9/-3, Akt}

For extract preparation, the cells were washed twice with ice-cold $\mathrm{PBS} / \mathrm{BSA}$, scraped and centrifuged for $30 \mathrm{~min}$ at $4{ }^{\circ} \mathrm{C}$ in $1 \mathrm{ml}$ of lysis buffer ( $1 \%$ Triton, $0.5 \%$ sodium deoxycholate, $0.1 \mathrm{~N} \mathrm{NaCl}, 1 \mathrm{mM}$ EDTA, pH 7.5, $10 \mathrm{~mm} \mathrm{Na}_{2} \mathrm{HPO}_{4}, \mathrm{pH} 7.4,10 \mathrm{~mm}$ phenylmethylsulphonyl fluoride (PMSF), $25 \mathrm{mM}$ benzamidin, $1 \mathrm{~mm}$ leupeptin, $0.025 \mathrm{U} \mathrm{ml}^{-1}$ aprotinin). Equal amounts of cell proteins were separated by SDS-PAGE. The proteins on the gels were electrotransferred to nitrocellulose and reacted with the different MAbs. Nitrocellulose filters were subsequently exposed to HRPconjugated secondary antibodies. Finally, the film was washed with PBS/0.05\% Tween 20 and immunoreactive proteins were detected by the ECL, chemiluminescence technique (Amersham, Uppsala, Sweden).

\section{Analysis of $\mathrm{pKB} /$ Akt activity}

Akt assay was performed using reagents supplied as a kit obtained from Cell Signaling Technology Inc. (Cell Signaling Tech., Beverly, MA, USA). Briefly, $10^{6}$ PC cells were lysed in a buffer containig $20 \mathrm{~mm}$ Tris (pH 7.5), $150 \mathrm{~mm} \mathrm{NaCl}, 1 \mathrm{~mm}$ EDTA, 1 mM EGTA, $1 \%$ Triton $\mathrm{X}-100,2.5 \mathrm{~mm}$ sodium $\mathrm{PP}_{\mathrm{i}}, 1 \mathrm{~mm} \beta$-glycerophosphate, $1 \mathrm{~mm}$ $\mathrm{Na}_{3} \mathrm{VO}_{4}$ and $1 \mu \mathrm{g} \mathrm{ml}^{-1}$ leupeptin. Equal amounts of lysed proteins were immunoprecipitated overnight with sepharose-coupled antiAkt antibodies at $4{ }^{\circ} \mathrm{C}$. Immunocomplexes were washed four times with lysis buffer and twice with kinase buffer composed of $25 \mathrm{~mm}$ Tris (pH 7.5), $5 \mathrm{~mm} \quad \beta$-glycerophosphate, $2 \mathrm{~mm} \mathrm{DTT,} 0.1 \mathrm{~mm}$ $\mathrm{Na}_{3} \mathrm{VO}_{4}$ and $10 \mathrm{~mm} \mathrm{MgCl}_{2}$. Immune complexes were resuspended in $40 \mu \mathrm{l}$ of kinase buffer, supplemented with $200 \mu \mathrm{m} \mathrm{ATP}$ and $1 \mu \mathrm{g}$ of GSK- $3 \alpha / \beta$ fusion protein, and incubated at $30^{\circ} \mathrm{C}$ for $30 \mathrm{~min}$. The 
kinase reaction was stopped by the addition of $20 \mu$ lof $3 \times$ SDS sample buffer. Samples $(20 \mu \mathrm{l})$ were analysed by Western blotting with antiphospho-GSK-3 $\alpha / \beta$ antibody after PAGE separation.

\section{Immunofluorescence detection of actin}

Pancreatic cancer cells were seeded onto $35-\mathrm{mm}$ culture dishes on sterile coverslips and allowed to attach for $24 \mathrm{~h}$. Subsequently, the cells were incubated for $48 \mathrm{~h}$ in the presence of ZOL $(15 \mu \mathrm{M})$. The medium was then removed, cells washed with PBS and fixed with $1 \mathrm{ml}$ Cytofix/cytoperm (Pharmigen, CA, USA) for $45 \mathrm{~min}$ at $4^{\circ} \mathrm{C}$. Subsequently, the fixation buffer was removed and cells washed with $1 \mathrm{ml}$ of $1 \times$ washing buffer. For visualisation of filamentous actin, the cells were exposed to rhodamine-phalloidin $\left(100 \mu \mathrm{g} \mathrm{ml}^{-1}\right)$ (Sigma) for $10 \mathrm{~min}$ at $4^{\circ} \mathrm{C}$ and washed with washing buffer. After final washes, coverslips were mounted on the dishes using a $50 \%$ solution of glycerol in PBS. The cells were examined under a LEICA TCS SP2 confocal microscope.

\section{Statistical analysis}

Results are expressed as mean \pm s.e. The statistical significance of differences between the experimental points was analysed using the $t$-test; differences were considered significant when $P<0.05$.

\section{RESULTS}

\section{Zoledronic acid induces antiproliferative effects on PC cells}

The effect of ZOL on BxPC-3, CFPAC and PANC-1 PC cells was investigated in vitro using the MTT assay. Treatment with ZOL $(1-100 \mu \mathrm{M})$ produced a dose-dependent reduction of cell growth after $72 \mathrm{~h}$ of treatment (Figure $1 \mathrm{~A}$ ) and the $\mathrm{IC}_{50}$ was calculated in a range of $10-50 \mu \mathrm{M}$ (Figure 1B). Figure $1 \mathrm{C}$ and $\mathrm{D}$ show the morphological changes of cultured PC cells after $72 \mathrm{~h}$ exposure to ZOL $(50 \mu \mathrm{M})$. Untreated cells (Figure 1C) were flat and well spread, but exposure to the drug (Figure 1D) resulted in significant antiproliferative effects, retraction of cells from the substratum, rounding up and loss of contact between neighbouring cells. Altogether, these findings indicate that ZOL exerts growth inhibitory activity on PC cells.

\section{Zoledronic acid induces apoptotic death of PC cells}

To clarify the mechanisms of ZOL-induced growth inhibition, we performed apoptotic assays on PC cells exposed to this compound. Activation of apoptosis was detected by Annexin- $\mathrm{V}$ staining, which is early expressed on the outer side of the cell membrane only when apoptosis is triggered and by PI which directly measures fragmented DNA. Figure 2 shows the apoptotic death of BxPC-3,

\section{A}

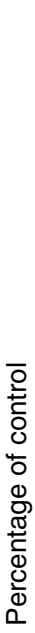


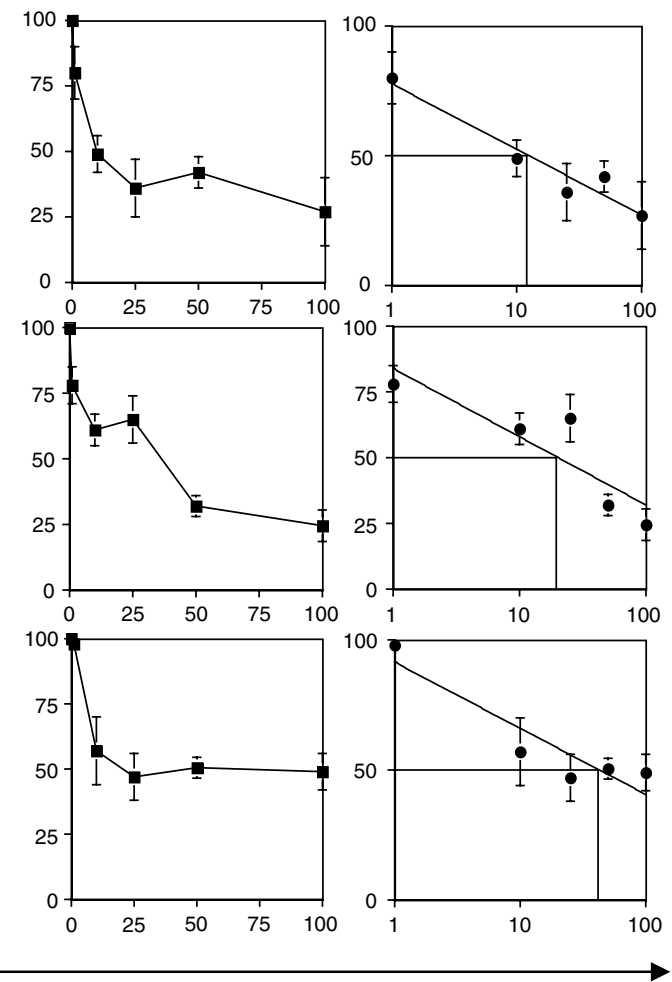

C
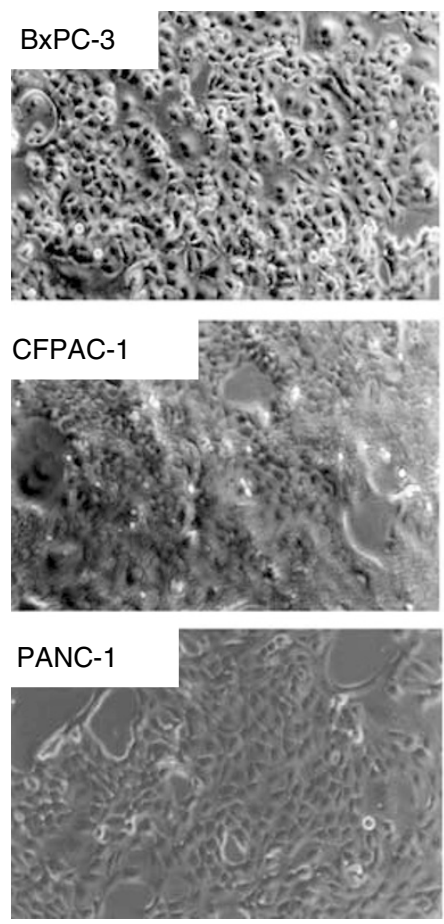

D
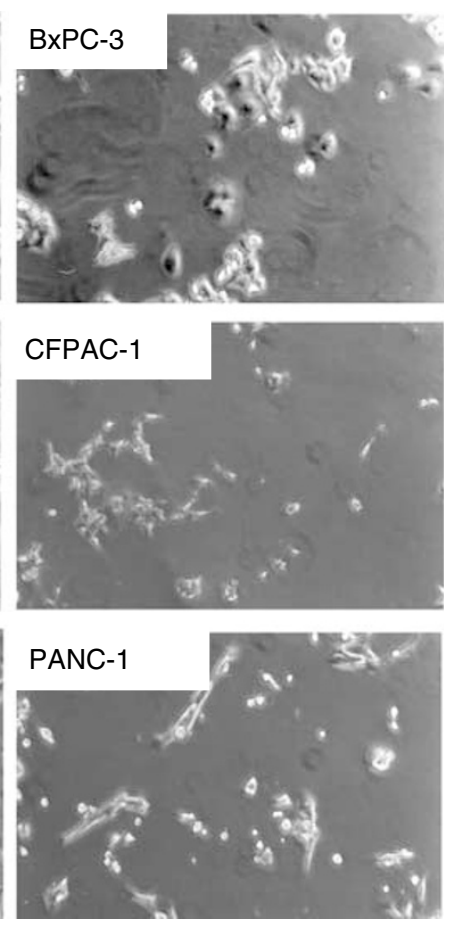

ZOL concentration $(\mu \mathrm{M})$

Figure I Zoledronic acid inhibits the growth of PC cells. (A) The cell lines BxPC-3, CFPAC-I and PANC-I $\left(3 \times 10^{4} \mathrm{ml}^{-1}\right)$ were seeded in $96-\mathrm{well}$ plates and incubated for $24 \mathrm{~h}$. After $24 \mathrm{~h}$, medium was removed and replaced with medium containing increasing concentrations of $Z \mathrm{OL}$ ( I - I00 $\mu \mathrm{M}$ ). After $72 \mathrm{~h}$ of incubation, cell proliferation was determined by the MTT assay. A value of $100 \%$ was assigned to untreated control cultures, and the antiproliferative effects of $\mathrm{ZOL}$ were calculated as percentage of residual growth. Each point is the mean value of at least four replicate experiments \pm s.e. (B) The $\mathrm{C}_{50}$ drug concentration for each cell line was measured by a logarithmic interpolate curve on the percentage of residual growth at each concentration point (C and D) Morphological changes induced in cell cultures after $72 \mathrm{~h}$ exposure to ZOL. Analysis was performed by inverted phase-contrast microscopy. (C) Untreated cultures; (D) treated cultures with ZOL $(50 \mu \mathrm{M})$. 
A

CFPAC-1

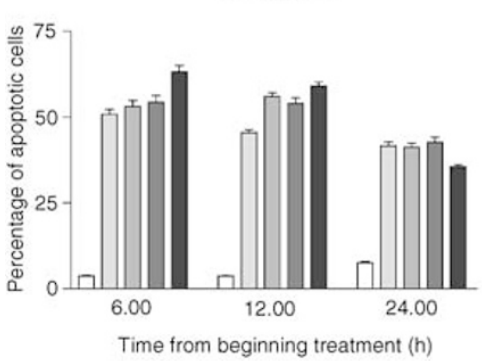

BxPC-3

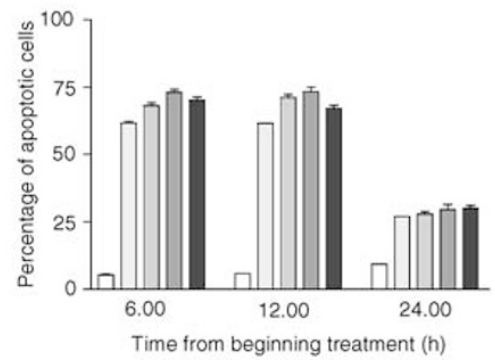

PANC-1

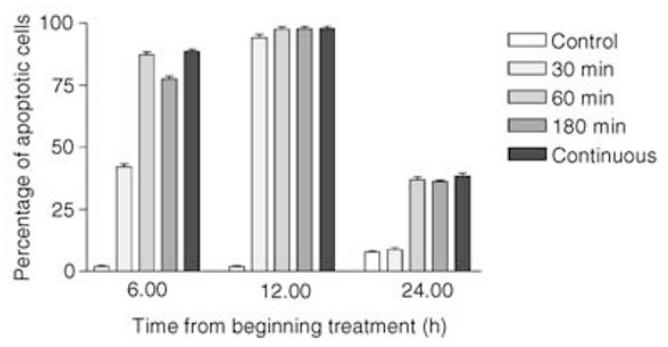

B CFPAC-1

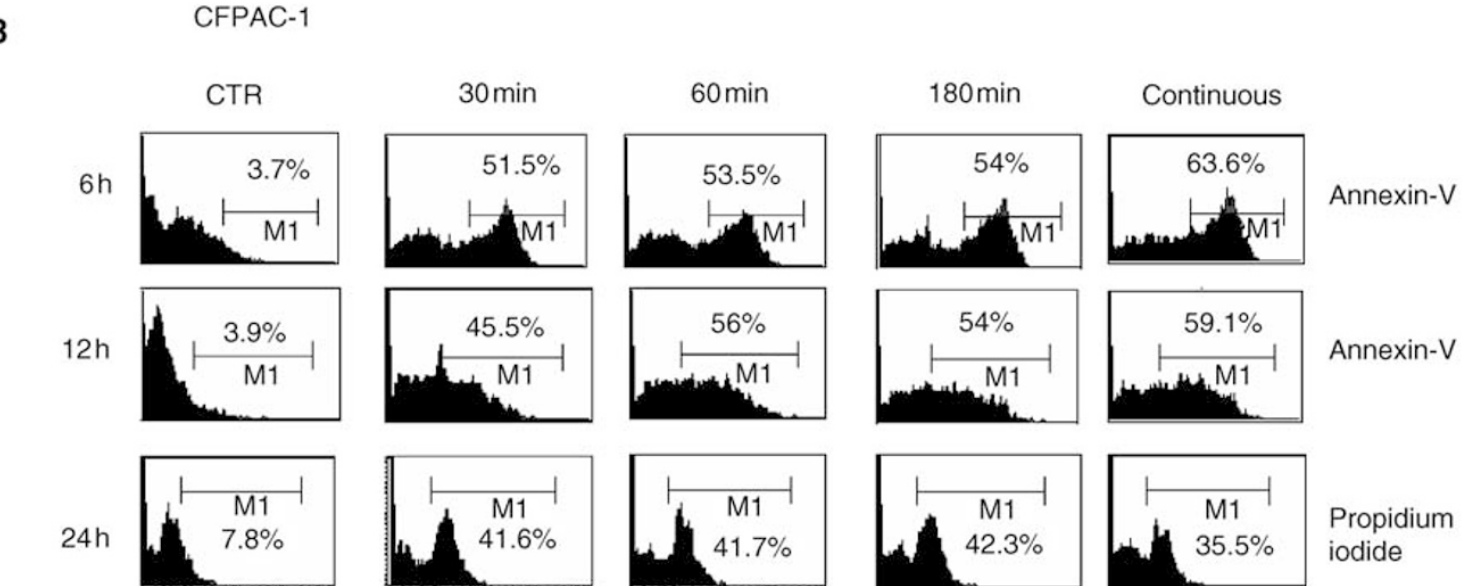

Figure 2 (A) Apoptotic effects induced by ZOL on CFPAC-I, PANC-I, BxPC-3 PC cancer cells. The analysis of apoptosis was performed after exposure to $50 \mu \mathrm{M}$ of ZOL by flow cytometric detection of Annexin- $V$ immunostaining. Cells were pulse exposed for 30,60 and I 80 min or continuously exposed to the drug. The PI method was used when apoptosis was evaluated $24 \mathrm{~h}$ after beginning treatment. Data are expressed as the mean value of at least four replicate experiments \pm s.e. (B) Flow cytometric profiles from a representative experiment performed on CFPAC-I cells. The percentage of apoptotic stained cells (\%) is indicated in each quadrant.

CFPAC-1 and PANC-1 cells after 6,12 and $24 \mathrm{~h}$ exposure to $50 \mu \mathrm{M}$ ZOL. Apoptotic cell death was detected in $35-90 \%$ of treated PC cells, suggesting a significant role of apoptotic death in the in vitro activity of ZOL. Notably, induction of the apoptosis was independent from the length of ZOL exposure. After 6-12 h from the beginning of ZOL exposure, Annexin-V staining was equally detected in cells treated by a $30-180$ min pulse as compared with cells treated with continuous drug exposure, suggesting that induction of the apoptotic process is an early event in pancreatic cells exposed to ZOL. DNA fragmentation demonstrated by the PI experiment became evident after $24 \mathrm{~h}$ and again was independent from the length of exposure (pulse $v s$ continuous).

\section{Caspase- and PARP-dependency of ZOL-induced apoptosis in PC cells}

We investigated the molecular mechanisms of ZOL-induced apoptosis in these cells. We found that exposure of PC cells to ZOL increased PARP cleavage, a key enzyme in the apoptotic cascade, as demonstrated by Western blot analysis, which showed a higher expression of the $116 \mathrm{kDa}$ proenzyme and the appearance of an $89 \mathrm{kDa}$ cleavage product in treated cells. The maximal effect was detected after $72 \mathrm{~h}$ of $\mathrm{ZOL}$ exposure (Figure $3 \mathrm{~A}$ ). We also found that caspase- 9 was cleaved/activated after cell exposure to the drug, while no effect was detected on caspase-3. These data were confirmed by the use of specific caspase inhibitors. We demonstrated that the caspase-9 inhibitor Z-VAD and the specific caspase- 6 inhibitor VEID almost completely prevented apoptotic death of PC cells, while the DEVD caspase- 3 inhibitor only slightly affected apoptosis induced by ZOL, as detected by flow cytometric analysis of Annexin- $\mathrm{V}$ staining (Figure 3B). These findings suggest that apoptosis induced by ZOL on human PC cells is caspase-9-, caspase-6- and PARP-dependent, but caspase-3-independent.

\section{Zoledronic acid inhibits the $\mathrm{p} 21^{\mathrm{ras}} / \mathrm{Raf1/MEK/ERK1-2}$} mitogenic and $\mathrm{pKB} / \mathrm{Akt}$ antiapoptotic pathways in PC cells

In order to investigate the molecular mechanism of ZOL-induced growth inhibitory activity, we analysed whether the drug would affect the function of the ras/raf1/MEK/ERK1-2 pathway. We observed a strong decrease of the intracellular content of $\mathrm{p} 21^{\mathrm{ras}}$ and of its substrate Raf- 1 as evaluated by Western blotting (Figure $4 \mathrm{~A}$ and $\mathrm{B}$ ). In fact, $48 \mathrm{~h}$ treatment with $50 \mu \mathrm{M}$ ZOL induced a twoto-three-fold reduction of the expression of the two signalling components (Figure 4A and B). Subsequently, we studied the effects of ZOL on the activity of ERK1-2, the terminal enzyme of the ras/raf-1 antiapoptotic and survival pathway. We found a strong decrease of the activity of the two enzymes, as demonstrated by the immunodetection of the phosphorylated forms of ERK1-2 (Figure 4E). On the other hand, no changes in the intracellular levels of ERK1-2 were found in the ZOL-treated PC cells (Figure 4D). These data suggest a significant inhibition of the signalling activity of this mitogenic and survival pathway. Another important and ras-dependent survival pathway of human cancer cells is mediated by the activation of the intracellular kinase $\mathrm{pKB} /$ Akt. Therefore, we also studied the effects of ZOL on Akt activity. We observed a significant impairment of pKB/Akt activity in cells exposed to ZOL as demonstrated by reduced phosphorylation of 
A

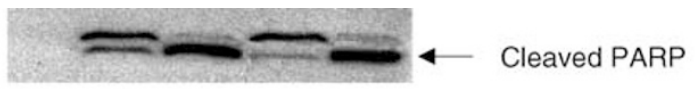

$-4-\quad$ Cleaved caspase-9

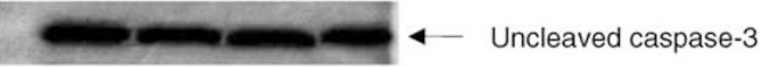

$\frac{\text { CTR ZOL }}{\text { BXPC-3 }} \quad \frac{\text { CTR ZOL }}{\text { PANC-1 }}$

B

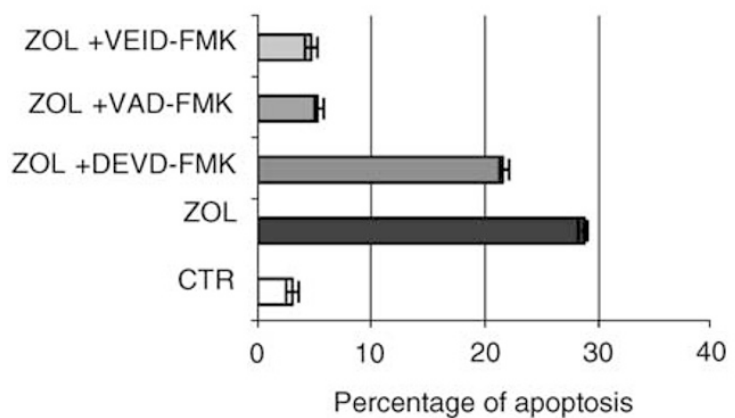

Figure 3 Role of caspase-9/-3 and PARP in apoptotic cell death induced by ZOL. (A) Detection of caspase-9/-3 and PARP in PC cells after ZOL treatment. Western blotting analysis was performed on protein extracts from solubilized whole cell pellets from BxPC-3 and PANCI PC cell lines after $48 \mathrm{~h}$ exposure to $\mathrm{ZOL}(50 \mu \mathrm{M})$ demonstrating abundant cleaved species of both caspase- 9 and PARP in lysates for drug-exposed cells, while caspase- 3 remained almost completely uncleaved. The experiments were performed at least three times and the results were always similar. (B) Apoptotic effects induced by $\mathrm{ZOL}$ in the presence of caspase inhibitors. Analysis was performed by flow cytometric immunodetection of Annexin$V$ staining on BxPC-3 cells after $48 \mathrm{~h}$ exposure to ZOL $(50 \mu \mathrm{M})$. VAD is a caspase-9 inhibitor, VEID is a specific caspase-6 inhibitor and DEVD is a caspase-3 inhibitor. Pretreatment with I5 $\mu \mathrm{M}$ VAD and I5 $\mathrm{M}$ VEID significantly antagonised ZOL-induced apoptosis $(P<0.005)$.

the GSK $3 \alpha / \beta$ fusion protein induced by the immunoprecipitated Akt (Figure $4 \mathrm{~F}$ ). We conclude that ZOL interferes with signalling pathways, which mediate proliferative stimuli and protect tumour cells from triggering apoptosis.

\section{Zoledronic acid induces actin cytoskeletal reorganisation in PC cells}

Finally, we studied whether the morphological changes induced in PC cells after exposure to ZOL occurred together with cytoskeletal reorganisation, which is considered to antagonise cell migration and invasion (Nobes and Hall, 1995). After $48 \mathrm{~h}$ exposure to ZOL $(15 \mu \mathrm{M})$, we observed reorganisation of the cytoskeleton and cortical actin polymerisation as judged by confocal microscopy detection of phalloidin-stained actin filaments. At these concentrations and exposure time, ZOL did not induce increased apoptotic death as compared with untreated cells. Figure 5 shows cytoskeletal rearrangements into cortical rings after the treatment. These findings suggest that the drug may trigger apoptotic death of PC cells, at least in part by interfering with cytoskeletal integrity.

\section{DISCUSSION}

In this study, we have demonstrated that the most potent antiresorptive nitrogen-containing BP ZOL causes antiproliferative
A

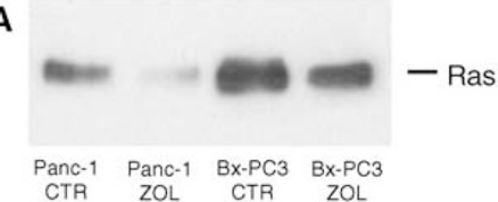

B

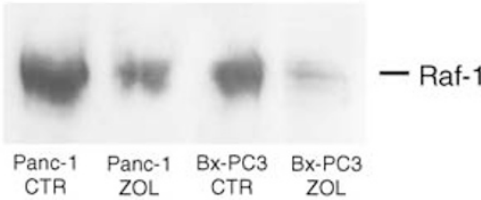

C

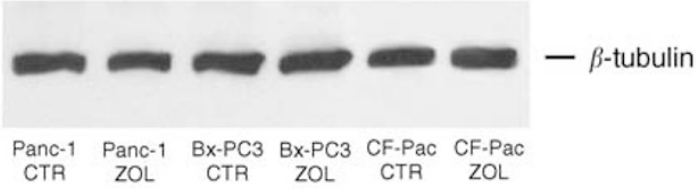

D

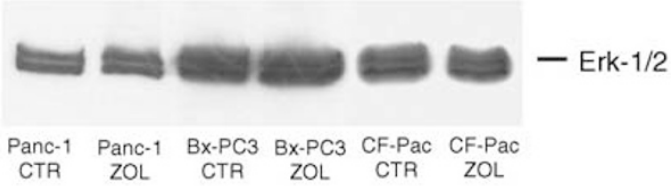

E

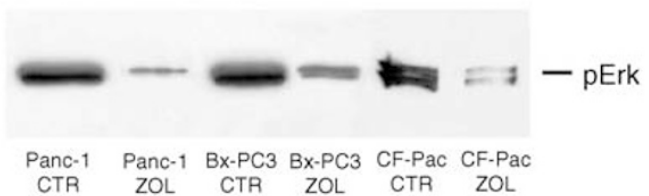

$\mathbf{F}$

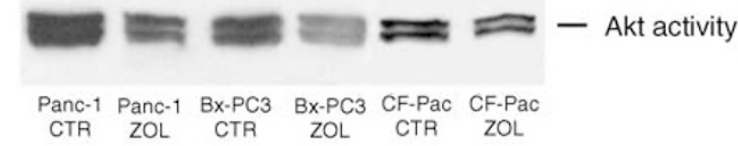

G

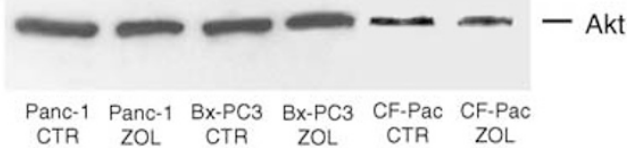

Figure 4 Effects of ZOL treatment on $\mathrm{p} 2 \mathrm{I}^{\mathrm{ras}} /$ Raf-I/MEKI/ERK signalling and PK-B/Akt pathways in PC cells. Western blotting analysis of $\mathrm{p} 2 \mathrm{I}^{\text {ras }}(\mathbf{A})$, raf-I (B), Erk-I/2 (D) and pErk (E). The immunoblotting shows downregulation of $22 \mathrm{I}^{\text {ras }}(\mathbf{A})$ and raf- $\mathrm{I}$ (B) levels after $48 \mathrm{~h}$ of exposure to $50 \mu \mathrm{M} Z \mathrm{OL}$. While no significant effects were detected on Erk-I/2 expression after exposure of cells to the drug (D), the active phosphorylated Erk-I/2 (recognised by an anti-pERK Mab) levels were greatly reduced in ZOL-treated cells $(\mathbf{E})$. (F and $\mathbf{G}$ ) Akt expression and functional analysis in BxPC-3, PANC-I and CFPAC-I pancreatic adenocarcinoma cells. For detection of Akt activity, immunoprecipitation was performed from cell lysates with anti-Akt antibody, and an in vitro kinase assay was performed using GSK $3 \alpha / \beta$ as a substrate, followed by Western blotting analysis with antiphospho-GSK3 $\alpha / \beta$. GSK3 $\alpha / \beta$ phosphorylation by immunoprecipitated Akt was downregulated after $48 \mathrm{~h}$ treatment of PC cells with $50 \mu \mathrm{M} Z \mathrm{ZL}(\mathbf{F})$, whereas the Akt protein levels remained unmodified. The experiments were performed at least three times and the results were always similar. CTR: untreated cells; ZOL: ZOL-treated cells. 

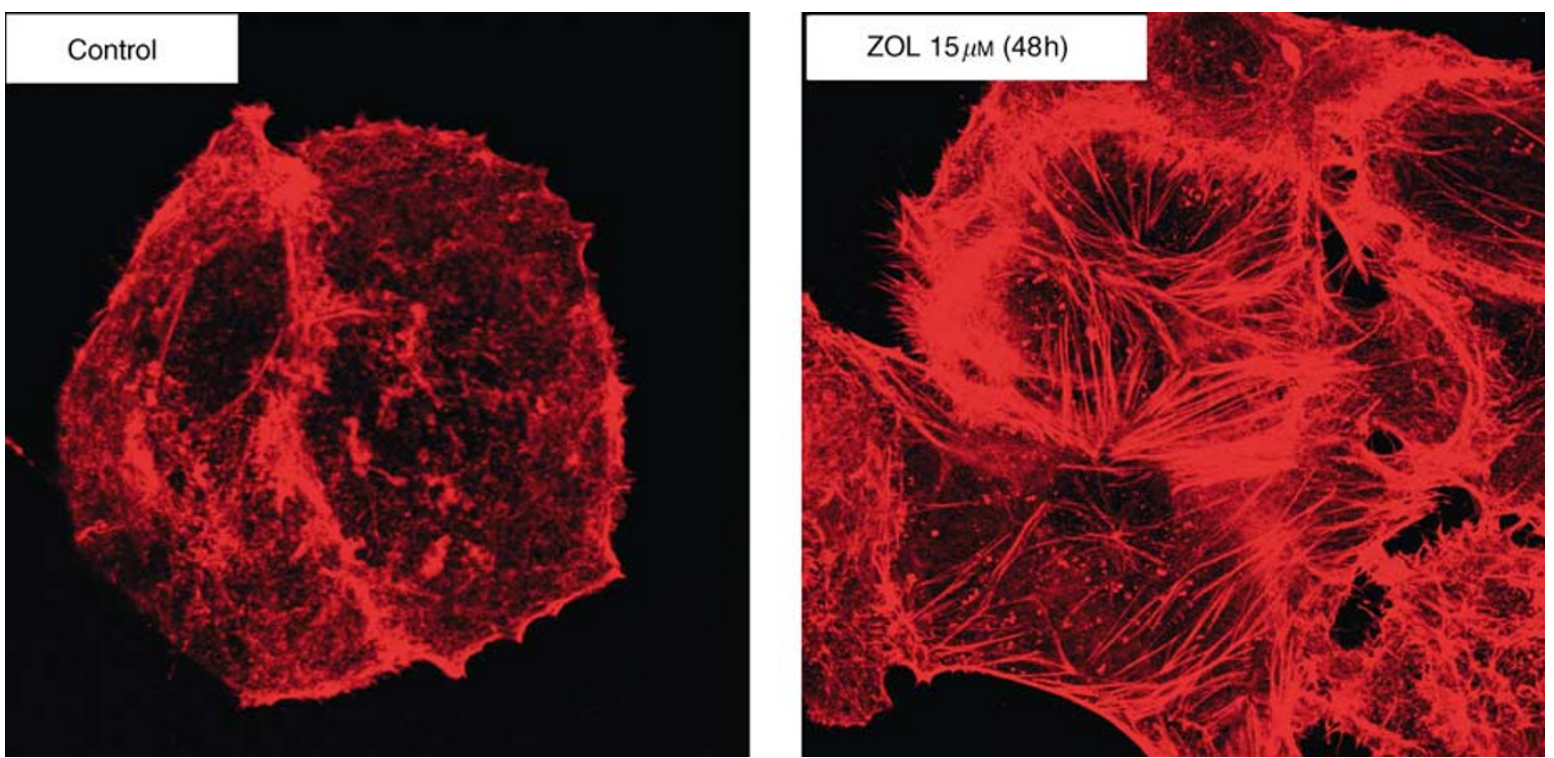

Figure 5 Analysis of cytoskeletal reorganisation by confocal microscopy on PANC-I PC cells after $48 \mathrm{~h}$ exposure to ZOL (I5 $\mu \mathrm{M}$ ). The figure shows actin architecture rearrangements in cortical rings. The cells were examined under a confocal microscope at a magnification of $\times 100$. The experiments were performed at least three times and the results were always similar.

effects, perturbation of the $21^{\text {ras }} /$ Raf1/MEK/ERK1-2 mitogenic pathway and $\mathrm{pKB} / \mathrm{Akt}$ survival signalling, and also induces apoptotic death of human PC cells in vitro. We have also shown that the apoptotic events induced by the drug directly involve activation of caspase- 9 , caspase- 6 and PARP. The present study provides the first evidence that a nitrogen-containing BP can directly interfere with intracellular mitogenic and survival pathways downstream to $\mathrm{p} 21^{\text {ras }}$ and produce antitumour effects in cultured PC cells.

Bisphosphonates are an emerging class of drugs mostly used in the palliative care of cancer patients. These compounds are specific inhibitors of osteoclastic activity and may significantly reduce skeletal complications, thereby sustaining the quality of life of cancer patients. There is a growing interest in the possibility that BPs may also improve survival in these patients. Several properties of BPs have been recently highlighted. Experimental findings suggest that these drugs may directly act on cancer cells, either by inhibiting tumour cell invasion or adhesion to bone matrix or by inducing growth inhibitory and/or apoptotic cell death. This proapoptotic ability of BPs has been strongly correlated with the specific antiresorptive potency of each compound. Specifically, it has been demonstrated that ZOL has a direct effect on human multiple myeloma (Shipman et al, 1997), breast cancer (Senaratne et al, 2000), prostate cancer (Lee et al, 2001) and melanoma cells (Riebeling et al, 2002).

We found that ZOL induces significant antiproliferative effects in a range of $10-50 \mu \mathrm{M}$. These data agree with most other in vitro studies showing maximal growth inhibitory effects of BPs at doses higher than what is persistently achievable in the serum of patients after treatment. In fact, it has been shown that infusion of Pamidronate, which is a less potent antiresorptive BP commonly used in palliative treatments, gives serum concentrations $\sim 10$-fold lower $(0.5-8 \mu \mathrm{M})$ (Daley-Yates et al, 1991; Oiso et al, 1994; Berenson et al, 1997).

It is well known that BPs have a rapid clearance from the blood stream and therefore only effects induced by short-term exposure have a clinical relevance for extra bone antitumour activity. We have indeed that induction of apoptotic death in PC cells occurs after only $30 \mathrm{~min}$ pulse exposure and does not require continuous drug exposure. We think therefore that this latter finding increases the potential translational fall-out of this study. Moreover, we consider of interest that PC has been reported to metastasize to bone in approximately $15 \%$ of the cases. The low rate of bone involvment is not unexpected, because only with the recent improvements in diagnosis and treatment PC patients begin to survive long enough to reach the stage of disease most associated with distant skeletal lesions. Even if it has not been stated which bone sites may be specifically involved in metastatic spread, it has been suggested that PC metastasises to bone in a pattern that predominantly favours the pelvic girdle (Lyons et al, 2001). These lesions may heavily affect the quality of life of advanced cancer patients and overall survival. Therefore, our data strengthen the rationale for the use of these drugs in a palliative treatment of skeletal metastatic disease. It has however to be underlined that palliative effects on the metastasis at the bone site do not necessarily involve direct antitumour activity.

The molecular bases of the $\mathrm{BP}$ antitumour activity remain to be elucidated. However, one possible mechanism is based on the ability of BPs to inhibit some of the enzymes involved in the pathway for cholesterol synthesis. Relevant to our study, dysregulation of $\mathrm{p} 21^{\text {ras }}$ activity appears to be a critical event for the onset of PC. We have shown that ZOL interferes with the $\mathrm{p} 21^{\text {ras }} / \mathrm{raf}-1 / \mathrm{MEK} 1 / \mathrm{ERK}$ and $\mathrm{pKB} /$ akt signalling cascades, as $\mathrm{p} 21^{\text {ras }}$ and Raf- 1 contents were clearly reduced in PC cells, and the active phosphorylated species of ERK1-2-, and pKB/akt-mediated phosphorylation of GSK $\alpha / \beta$ were strongly downregulated in cells exposed to the drug. These data appear to be of specific interest considering the widely described growth promoting and antiapoptotic activity of the two p2 $1^{\text {ras }}$-dependent raf-1/MEK1/ERK and $\mathrm{pKB} / \mathrm{Akt}$ pathways, and our study provides, at our knowledge, the first evidence that $\mathrm{ZOL}$ affects the intracellular signalling pathway downstream to $\mathrm{p} 21^{\text {ras }}$. Moreover, it has been demonstrated that Akt directly inhibits caspase- 9 activity by phosphorylation and, intriguingly, we demonstrated that in our experimental model ZOL-induced apoptosis is caspase-9-dependent (Fujita et al, 1999; Zhou et al, 2000). In fact, we demonstrated that, in parallel with the antiproliferative effects mediated by the drug, ZOL also induces apoptotic cell death in PC cells. Cell death by an apoptotic process is a well-described phenomenon that is associated with multiple molecular events. The caspase family of cysteine proteases are central participants in apoptotic cell death. Recent studies have highlighted the potential role of caspase- 9 as a 
selective target for anticancer treatment. It is also believed that chemotherapeutic agent-induced apoptosis is predominantly accomplished by activation of the mitochondrial pathway $(\mathrm{Wu}$ and Ding, 2002). In fact, blockade of caspase-9 decreases chemotherapeutic agent-induced mitocondrial-dependent apoptosis. In this context our observations are in agreement with other studies which reported that ZOL-mediated apoptosis is associated with cytochrome $c$ release and consequent caspase activation (Senaratne et al, 2002). Caspase-3 is considered to be involved in the execution phase of apoptosis, when proteolysis of intracellular substrates is a major event. It has been shown that BP-induced osteoclast apoptosis is dependent on caspase- 3 activation since cell death is prevented by caspase- 3 inhibitors, thereby suggesting the key role of these proteases in apoptotic cell death induced by these drugs (Benford et al, 2001). Caspase-3 has also been involved in apoptotic death of breast cancer cells exposed to ZOL (Senaratne et al, 2002). In our study however, we have been unable to find a specific role for caspase-3, which is not cleaved/activated, and apoptosis was only slightly antagonised by selective caspase- 3 inhibition. Our observations are in accordance with others who found no correlation between the amount of processing of caspase9 and effector caspases in human pancreatic carcinoma (Gerhard et al, 2002). We can therefore hypothesise that in ZOL-exposed PC cells, a caspase-9- and caspase-6-dependent and caspase-3independent pathway is operative, while in other tumour cell systems, as well as in normal osteoclast cells, execution of apoptosis induced by ZOL may occur by a caspase-3-dependent mechanism. The possible identification of tissue-specific executioners of apoptosis might be ideal subjects of investigation, and may have the advantage of enhancing selectivity in therapeutical intervention.

Activation of caspases during cell death is commonly associated with characteristic intracellular changes of in vitro cultured cells, including loss of adhesion, actin-cytoskeletal structural reorganisation into cortical rings, cell rounding and contracting, and generation of apoptotic bodies. A role for caspase-mediated proteolysis of structural and adhesion proteins has been suggested in the morphological changes that characterise apoptotic cell death. After the initial phase of contraction and blebbing, caspasemediated cleavage of actin monomers probably induces disassembly of actin filaments (Mashima et al, 1997; McCarthy et al, 1997). We found that after $48 \mathrm{~h}$ of low concentration ZOL treatment, significant actin-cytoskeletal reorganization occurs in
PC cells as demonstrated by actin staining. These modifications indicate that ZOL induces actin rearrangements into cortical rings and that these events may drive the cells to the apoptotic process. This specific effect indicates the intriguing possibility of positive interactions of BPs with drugs that interfere with actin polymerisation and depolymerisation such as taxoid or vinca alkaloid agents. A synergistic effect of ZOL with paclitaxel has in fact been demonstrated in human breast cancer (Jagdev et al, 2001). Recent reports have also highlighted the role of signal transduction pathways controlled by the Rho family of small GTPases in regulating the architecture of the actin cytoskeleton and the morphological changes during apoptotic cell death (Coleman and Olson, 2002). An intriguing preliminary finding is that the small GTP-binding protein RAC, functionally related to cytoskeletal organisation, discloses enhanced (10-fold) expression in ZOLexposed cancer cells as detected by Western blot analysis (data not shown). Based on these findings, further studies are presently in progress in order to understand the functional significance of these observations.

In conclusion, we have demonstrated that PC cells are highly sensitive to ZOL-induced growth perturbation and induction of apoptosis, which is caspase-9- caspase-6- and PARP-dependent. Moreover, our experimental findings suggest that inhibition of p21 ras/Raf-1/MEK1/ERK signalling as well as PK-B/Akt inhibition might be relevant for the antitumour effects of ZOL. Although we have been capable of demonstrating that a short-term exposure is enough for activation of apoptosis, we think that a pharmacokinetic profile more relevant to the extra-bone antitumour effects of ZOL should be derived and might involve entrapping of BPs in lysosomes. An additional topic of current investigation is $\mathrm{BP}$ combination with cytotoxic drugs or selective signal transduction inhibitors.

\section{ACKNOWLEDGEMENTS}

P Tassone was supported by a fellowship from FIRC (Fondazione Italiana per la Ricerca sul Cancro). This work was supported in part by funds from Regione Calabria (POP 94/99) (Italy), MURSTCNR Biotechnology Program L. 95/95 (Italy), MURST (Cofin 98, 99), Consiglio Nazionale delle Ricerche (Special Project Biotechnology) and by a grant from the Italian Ministry of Health, FSN 2000 .

\section{REFERENCES}

Almoguera C, Shibata D, Forrester K, Martin J, Arnheim N, Perucho M (1988) Most human carcinomas of the exocrine pancreas contain mutant c-Kras gene. Cell 53: 549-554

Aparicio A, Gardner A, Tu Y, Savage A, Berenson J, Lichtenstein A (1998) In vitro cytoreductive effects on multiple myeloma cells induced by bisphosphonates. Leukemia 12: 220-229

Benford HL, Frith JC, Auriola S, Monkkonen J, Rogers MJ (1999) Farnesol and geranylgeraniol prevent activation of caspases by aminobisphosphonates: biochemical evidence for two distinct pharmacological classes of bisphosphonate drugs. Mol Pharmacol 56: $131-140$

Benford HL, McGowan NW, Helfrich MH, Nuttall ME, Rogers MJ (2001) Visualization of bisphosphonate-induced caspase-3 activity in apoptotic osteoclasts in vitro. Bone 28: 465-473

Berenson JR, Lichtenstein A, Porter L, Dimopoulos MA, Bordoni R, George S, Lipton A, Keller A, Ballester O, Kovacs M, Blacklock H, Bell R, Simeone JF, Reitsma DJ, Heffernan M, Seaman J, Knight RD (1998) Long-term pamidronate treatment of advanced multiple myeloma patients reduces skeletal events. Myeloma Aredia Study Group. J Clin Oncol 16: 593-602

Berenson JR, Rosen L, Vescio R, Lau HS, Woo M, Sioufi A, Kowalski MO, Knight RD, Seaman JJ (1997) Pharmacokinetics of pamidronate disodium in patients with cancer with normal or impaired renal function. J Clin Pharmacol 37: 285-290
Boissier S, Magnetto S, Frappart L, Cuzin B, Ebetino FH, Delmas PD, Clezardin P (1997) Bisphosphonates inhibit prostate and breast carcinoma cell adhesion to unmineralized and mineralized bone extracellular matrices. Cancer Res 57: 3890-3894

Carano A, Teitelbaum SL, Konsek JD, Schlesinger PH, Blair HC (1990) Bisphosphonates directly inhibit the bone resorption activity of isolated avian osteoclasts in vitro. J Clin Invest 85: 456-461

Coleman ML, Olson MF (2002) Rho GTPase signalling pathways in the morphological changes associated with apoptosis. Cell Death Differ 9: 493-504

Daley-Yates PT, Dodwell DJ, Pongchaidecha M, Coleman RE, Howell A (1991) The clearance and bioavailability of pamidronate in patients with breast cancer and bone metastases. Calcif Tissue Int 49: 433-435

Dhodapkar MV, Singh J, Mehta J, Fassas A, Desikan KR, Perlman M, Munshi NC, Barlogie B (1998) Anti-myeloma activity of pamidronate in vivo. Br J Haematol 103: 530-532

Fernandez E, La Vecchia C, Porta M, Negri E, Lucchini F, Levi F (1994) Trends in pancreatic cancer mortality in Europe, 1955-1989. Int J Cancer 57: $786-792$

Fujita E, Jinbo A, Matuzaki H, Konishi H, Kikkawa U, Momoi T (1999) Akt phosphorylation site found in human caspase- 9 is absent in mouse caspase-9. Biochem Biophys Res Commun 264: 550-555 
Gerhard MC, Schmid RM, Hacker G (2002) Analysis of the cytochrome $c$ dependent apoptosis apparatus in cells from human pancreatic carcinoma. Br J Cancer 86: $893-898$

Green JR (2001) Chemical and biological prerequisites for novel bisphosphonate molecules: results of comparative preclinical studies. Semin Oncol 28: 4-10

Green JR, Muller K, Jaeggi KA (1994) Preclinical pharmacology of CGP 42'446, a new, potent, heterocyclic bisphosphonate compound. J Bone Miner Res 9: $745-751$

Hilgers W, Kern SE (1999) Molecular genetic basis of pancreatic adenocarcinoma. Genes Chromosomes Cancer 26: 1-12

Hughes DE, Wright KR, Uy HL, Sasaki A, Yoneda T, Roodman GD, Mundy GR, Boyce BF (1995) Bisphosphonates promote apoptosis in murine osteoclasts in vitro and in vivo. J Bone Miner Res 10: 1478-1487

Jagdev SP, Coleman RE, Shipman CM, Rostami H, Croucher PI (2001) The bisphosphonate, zoledronic acid, induces apoptosis of breast cancer cells: evidence for synergy with paclitaxel. Br J Cancer 84: 1126-1134

Jung A, Bisaz S, Fleisch H (1973) The binding of pyrophosphate and two diphosphonates by hydroxyapatite crystals. Calcif Tissue Res 11: 269280

Lee MV, Fong EM, Singer FR, Guenette RS (2001) Bisphosphonate treatment inhibits the growth of prostate cancer cells. Cancer Res 61: $2602-2608$

Luckman SP, Hughes DE, Coxon FP, Graham R, Russell G, Rogers MJ (1998) Nitrogen-containing bisphosphonates inhibit the mevalonate pathway and prevent post-translational prenylation of GTP-binding proteins, including Ras. J Bone Miner Res 13: $581-589$

Lyons JD, Alibazoglu B, Harris JE, Ali A, Hollinger EF (2001) Pelvic metastases from pancreatic carcinoma: a pattern observed on bone scan. Clin Nucl Med 26: 230-231

Mashima T, Naito M, Noguchi K, Miller DK, Nicholson DW, Tsuruo T (1997) Actin cleavage by CPP-32/apopain during the development of apoptosis. Oncogene 14: $1007-1012$

McCarthy NJ, Whyte MK, Gilbert CS, Evan GI (1997) Inhibition of Ced-3/ ICE-related proteases does not prevent cell death induced by oncogenes, DNA damage, or the Bcl-2 homologue Bak. J Cell Biol 136: 215-227

Nobes CD, Hall A (1995) Rho, rac, and cdc42 GTPases regulate the assembly of multimolecular focal complexes associated with actin stress fibers, lamellipodia, and filopodia. Cell 81: 53-62

Oiso Y, Tomita A, Hasegawa H, Ariyoshi Y, Niinomi M, Yamamoto M, Takano T, Sakiyama N (1994) Pamidronate treatment in patients with tumor-associated hypercalcemia: pharmacological effects and pharmacokinetics. Endocr J 41: 655-661

Parker SL, Tong T, Bolden S, Wingo PA (1996) Cancer statistics, 1996. CA Cancer J Clin 46: 5-27

Pelger RC, Hamdy NA, Zwinderman AH, Nijeholt AA, Papapoulos SE (1998) Effects of the bisphosphonate olpadronate in patients with carcinoma of the prostate metastatic to the skeleton. Bone 22: 403-408

Riebeling C, Forsea AM, Raisova M, Orfanos CE, Geilen CC (2002) The bisphosphonate pamidronate induces apoptosis in human melanoma cells in vitro. $\mathrm{Br} J$ Cancer 87: $366-371$

Sasaki A, Boyce BF, Story B, Wright KR, Chapman M, Boyce R, Mundy GR, Yoneda T (1995) Bisphosphonate risedronate reduces metastatic human breast cancer burden in bone in nude mice. Cancer Res 55: $3551-3557$

Sato M, Grasser W, Endo N, Akins R, Simmons H, Thompson DD, Golub E, Rodan GA (1991) Bisphosphonate action. Alendronate localization in rat bone and effects on osteoclast ultrastructure. J Clin Invest 88: 2095-2105

Senaratne SG, Mansi JL, Colston KW (2002) The bisphosphonate zoledronic acid impairs membrane localisation and induces cytochrome $c$ release in breast cancer cells. Br J Cancer 86: 1479-1486

Senaratne SG, Pirianov G, Mansi JL, Arnett TR, Colston KW (2000) Bisphosphonates induce apoptosis in human breast cancer cell lines. $\mathrm{Br}$ Cancer 82: 1459 - 1468

Shipman CM, Rogers MJ, Apperley JF, Russell RG, Croucher PI (1997) Bisphosphonates induce apoptosis in human myeloma cell lines: a novel anti-tumour activity. Br J Haematol 98: 665-672

Tassone P, Forciniti S, Galea E, Morrone G, Turco MC, Martinelli V, Tagliaferri P, Venuta S (2000) Growth inhibition and synergistic induction of apoptosis by zoledronate and dexamethasone in human myeloma cell lines. Leukemia 14: $841-844$

Tassone P, Galea E, Forciniti S, Tagliaferri P, Venuta S (2002) The IL-6 receptor super-antagonist Sant7 enhances antiproliferative and apoptotic effects induced by dexamethasone and zoledronic acid on multiple myeloma cells. Int J Oncol 21: $867-873$

Van Der PG, Vloedgraven H, van beek E, Wee-Pals L, Lowik C, Papapoulos $S$ (1996) Bisphosphonates inhibit the adhesion of breast cancer cells to bone matrices in vitro. J Clin Invest 98: 698-705

Wu GS, Ding Z (2002) Caspase 9 is required for p53-dependent apoptosis and chemosensitivity in a human ovarian cancer cell line. Oncogene 21: $1-8$

Zhou H, Li XM, Meinkoth J, Pittman RN (2000) Akt regulates cell survival and apoptosis at a postmitochondrial level. J Cell Biol 151: 483-494 